\title{
Al-Madãris
}

VOL. 2, NO. 2, 2021

E-ISSN: 2745-9950

https://journal.staijamitar.ac.id/index.php/almadaris

\section{PEMANFAATAN SAMPAH ANORGANIK SEBAGAI MEDIA PEMBELAJARAN DI MTsN SAFINATUSSALAMAH AL-MUNAWARAH}

\author{
Nuraini Fatmi \\ Universitas Malikussaleh \\ nurainifatmi@unimal.ac.id \\ Iryana Muhammad \\ Universitas Malikussaleh \\ Iryana.muhammad@unimal.ac.id
}

\begin{abstract}
This research was conducted with a team of lecturers from Malikussaleh University with the aim of realizing environmentalbased learning through the use of waste as a learning medium that sharpens the creativity of teachers and students. This research was conducted at Madrasah Tsanawiyah Safinatussalamah AlMunawarah. Dayah Safinatussalamah Al-Munawarah is located in Blang Panyang Village, Muara Satu District, Lhokseumawe City. The time of the research was carried out on August 9, 2021 and the place of research was at Madrasah Tsanawiyah Safinatussalamah AlMunawarah. The population in this study were all MTsN students at the Safinatussalamah Al-Munawarah Islamic Boarding School and the sample was the lst grade students of MTsN Safinatussalamah AlMunawarah. The research uses a 'qualitative' approach. The research conducted is descriptive. The instruments in this study were observation sheets and documentation. Data analysis techniques used in this study: (1) Data Collection, (2) Data Reduction, (3) Data Verification, (4) Drawing Conclusions. The results of the study can be concluded that this activity teaches students to love the environment by utilizing inorganic waste and making inorganic waste as a product of learning media can also increase student creativity and learning outcomes, this is because students better understand the concept of learning by seeing and working through learning media.
\end{abstract}

Keywords: Inorganic Waste, Learning Media

$\overline{\text { Al-Madãris, Volume 2 (2), } 2021}$ 


\section{A. Pendahuluan}

Pengembangan aplikasi IPA merupakan dasar dari terbentuknya teknologi dan industri yang secara tidak langsung akan mempengaruhi pola sosial manusia. Perkembangannya dilandaskan pada Ilmu pengetahuan yang berupa hipotesis, teori, dan hukum. Perkembangan tersebut menimbulkan dua konsepsi IPA, yaitu IPA klasik dengan telaahan bersifat Makroskopik dan IPA modern dengan telaahan bersifat Mikroskopik. Konsep klasik dan modern lebih mengacu pada konsepsi cara berpikir, cara memandang, dan cara menganalisis suatu fenomena alam "Bukan" pada waktu penemuannya.

Berdasarkan Kemendikbud, salah satu latar belakang pengembangan Kurikulum 2013 adalah adanya masalah lingkungan. Dengan dikembangkan Kurikulum 2013 ini, siswa diharapkan lebih memiliki rasa tanggungjawab terhadap lingkungan sekitar. Akan tetapi, masalah sampah di Indonesia nampak semakin memburuk akibat kurangnya kesadaran masyarakat dalam pengolahan sampah. Jumlah produksi sampah per tahun semakin tinggi sebanding dengan pertumbuhan penduduk, terutama sampah anorganik. Pengelolaan sampah dengan menerapkan prinsip 3R saat ini masih merupakan pengelolaan sampah yang terbaik dalam upaya mengurangi beban Tempat Pembuangan Sampah Akhir (TPA) (Ni Komang et al, 2008). Dampak sampah atau bahan bekas bagi manusia dan lingkungan sangat besar. Sudah kita sadari bahwa pencemaran lingkungan akibat per-industrian maupun rumah tangga sangat merugikan manusia, baik secara langsung maupun tidak langsung. Dengan memanfaatkan media bahan bekas untuk dijadikan media pembelajaran dapat menekan jumlah sampah di lingkungan sekitar. (Duda et al., 2018).

Berdasarkan hasil observasi awal penulis di lapangan, menemukan fenomena kehidupan selama ini yang terjadi di sekolah adalah sikap ketidak pedulian terhadap lingkungan, sebagai lembaga pendidikan, sekolah diharapkan mampu untuk membantu dalam penyelesaian masalah lingkungan ini. Sekolah tidak hanya tempat untuk tempat belajar, tetapi berperan penting untuk membantu siswa dalam memahami akibat perilaku manusia di bumi dan menjadi tempat untuk hidup secara berkelanjutan. Penanaman sikap kepedulian terhadap lingkungan sejak dini akan sangat membantu dalam membentuk kesadaran siswa terhadap pentingnya menjaga lingkungan. Meski pendidikan tentang lingkungan sangat penting ditanamkan sedini mungkin, madrasah stanawiyah juga memiliki peran yang sangat penting karena menjadi jenjang Pendidikan menengah untuk program wajib belajar. Ini adalah jenjang terakhir dimana sekolah dan guru dapat memberikan pondasi dasar tentang lingkungan sebelum peserta didik memilih jurusan untuk karir mereka.

Berdasarkan hasil wawancara penulis dengan kepala sekolah MTsN Safisatussalamah Al-Munawarah di desa Blang Panyang Kecamatan Muara Satu Kota Lhokseumawe, menemukan bahwa pembelajaran tentang lingkungan sangat erat kaitannya dengan pelajaran IPA. Oleh sabab itu, guru sebagai fasilitator pembelajaran diharapkan dapat memberikan pembelajaran IPA yang berkaitan dengan masalah-masalah lingkungan sekitar. Hal ini sesuai dengan imbauan dalam konsep Kurikulum 2013 untuk mata pelajaran IPA dan Matematika. Selain itu, mengaitkan pembelajaran dengan kehidupan yang 
sehari- hari siswa diyakini mampu menumbuhkan minat dan motivasi siswa dalam pelajaran.

Penelitian ini dilakukan bersama tim dosen Universitas Malikussaleh dengan tujuan untuk mewujudkan pembelajaran berbasis lingkungan. Terobosan pemikiran kembali konsep dasar pembaharuan Pendidikan, karena pendidikan sarana terbaik yang didesain untuk menciptakan suatu generasi baru pemuda-pemudi yang tidak akan kehilangan ikatan dengan tradisi mereka sendiri tapi juga sekaligus tidak menjadi bodoh secara intelektual atau terbelakang dalam pendidikan mereka atau tidak menyadari adanya perkembangan-perkembangan disetiap cabang pengetahuan manusia.

\section{B. Review Literatur}

Permasalahan lingkungan merupakan salah satu permasalahan yang tidak bisa dihindari. Saat ini, sampah menjadi masalah lingkungan yang sangat serius untuk dihadapi masyarakat Indonesia. Jumlah produksi sampah setiap tahun semakin bertambah seiring dengan bertambahnya jumlah penduduk. Pemerintah telah berupaya dengan berbagai cara untuk mengatasi masalah sampah. Namun, hasilnya masih belum mencapai titik kesempurnaan. Hal ini dikarenakan jumlah sampah yang ada di Indonesia sangat tinggi. Sehingga pemerintah kesulitan menentukan cara yang tepat untuk menyelesaikannya(Taufiq \& Maulana, 2015).

Permasalahan sampah tidak hanya terjadi di dalam rumah tangga, tetapi juga di sekolah. Sebagai sebuah komunitas dengan anggota yang besar, sekolah juga menjadi salah satu tempat penghasil sampah, baik itu sampah organik maupun sampah anorganik. Menurut Taufiq \& Maulana (2015), sampah organik adalah limbah yang bersal dari sisa makhluk hidup (alam) seperti hewan, manusia, tumbuhan yang mengalami pembusukan atau pelapukan. Sampah ini tergolong sampah yang ramah lingkungan karena dapat diurai oleh bakteri secara alami dan berlangsung cepat. Sedangkan sampah anorganik adalah sampah yang berasal dari sisa manusia yang sulit untuk di urai oleh bakteri, sehingga membutuhkan waktu yang cukup lama (hinga ratusan tahun) untuk dapat di uraikan.

Sampah organik dan anorganik tidak hanya ditemukan di lingkungan masyarakat maupun limbah rumah tangga tetapi juga banyak ditemukan di lingkungan sekolah. Di lingkungan sekolah sering ditemukan timbunan sampah anorganik terutama sampah plastik yang cukup mengganggu. Hal ini disebabkan karena pihak sekolah belum menemukan solusi penanganan yang tepat. Keterbatasan pengetahuan dan keterampilan sumberdaya memanfaatkan teknologi tepat guna menjadi kendala pihak sekolah (Widiyaningrum \& Purwantoyo, 2015). Dalam konteks pengelolaan sampah, partisipasi warga sekolah khususnya siswa, dapat diobservasi antara lain berdasarkan partisipasi saat pemilahan antara sampah organik dan sampah anorganik dalam proses pewadahan/penampungan, partisipasi dalam proses pengolahan, serta keinginan mengurangi penggunaan barang yang tidak mudah terurai (Nugraha et al., 2018).

Pengelolaan sampah di sekolah dapat dikategorikan dalam partisipasi langsung yaitu keikutsertaan dalam pengurangan pemakaian bahan yang sulit terurai, pemilahan sampah, pemindahan sampah dari sumber sampah ke tempat penampungan sementara, pemanfaatan kembali sampah, serta kegiatan 
kebersihan seperti gotong royong untuk kerja bakti di lingkungan (Manurung, 2008). Selain keterlibatan langsung dan tak langsung pengetahuan siswa mengenai akan menentukan tingkat partisipasinya dalam mengelola sampah untuk menjaga kebersihan lingkungannya(Riswan et al., 2015).

Kaitan antara keterampilan abad 21 dengan pengelolaan sampah ini adalah sebelum memanfaatkan sampah menjadi media pembelajaran yang mengasah kreativitas guru dan peserta didik. Terlebih dahulu siswa juga harus mengetahui perbedaan antara sampah organik dan anorganik melalui kegiatan pembelajaran dengan praktik pemilahan sampah organik dan anorganik baik secara individu maupun kelompok. Hal ini juga dilakukan untuk menanggulangi penumpukkan sampah dan memiliki karakter cinta akan kebersihan Setelah mereka paham tentang sampah organik dan anorganik maka pembelajaran dapat dilakukan dengan memanfaatkannya secara kreatif dan inovatif sebagai media pembelajaran.(Nurlaili, 2018).

Salah satu komponen pendidikan yang harus dilaksanakan oleh seorang guru untuk mewujudkan keberhasilan pelaksanaan strategi pembelajaran tersebut adalah dengan adanya pengadaan media pembelajaran. Penggunakan media pembelajaran dalam kegiatan belajar mengajar akan meningkatkan motivasi dan membantu mempermudah pemahaman peserta didik terhadap materi sehingga menciptakan pembelajaran yang bermakna. Seorang guru harus memiliki kemampuan dalam menciptakan media pembelajaran yang inovatif sehingga dapat meningkatkan pemahaman dan motivasi belajar peserta didik. Media pembelajaran sebagai alat bantu dalam kegiatan pembelajaran dapat dikembangkan secara sederhana dari beberapa sampah yang ada di lingkungan sekitar Dalam pembuatan media pembelajaran yang berasal dari sampah anorganik membutuhkan adanya keterampilan dalam belajar dan berinovasi.

Pembuatan media pembelajaran ini bukanlah suatu hal yang mudah, jika tidak diasah dan dibiasakan di sekolah karena membutuhkan adanya kreativitas yang cukup tinggi agar mengahasilkan media pembelajaran yang optimal. Dalam hal ini, media pembelajaran dibuat dengan memanfaatkan lingkungan sekolah sebagai sumber belajar. Setelah mereka paham tentang konsep sampah anorganik, para siswa diberikan kesempatan untuk mencarinya di lingkungan sekolah ataupun membawanya dari rumah. Kemudian mereka akan diajarkan untuk membuat media pembelajaran dengan bantuan guru.

Berdasarkan penelitian terdahulu, Pitri Ramadhan dan Vebrianton menyatakan bahwa Sejatinya media pembelajaran bertujuan untuk mempermudah proses pembelajaran baik untuk siswa maupun guru. Akan tetapi, terdapat kelemahan pada tiap-tiap produk/media yang telah diciptakan tersebut. Pada produk bingkai limbah anorganik yang peneliti buat ini, terdapat beberapa kelemahan/kekurangan yaitu: 1) proses pembuatan bingkai dari limbah anorganik jenis ini butuh waktu yang lama, apalagi jika dikerjakan sendiri: bisa menghabiskan waktu seharian; 2) untuk membuat bingkai dari limbah anorganik ini, membutuhkan ketelitian, kesabaran dan keuletan yang cukup tinggi. Karena memerlukan kreatifitas yang tinggi; dan 3) bahan yang digunakan dalam membuat bingkai ini hanya mengunakan limbah anorganik berupa kotak bekas dan sampah plastik.(Pitri Ramadan \& Vebrianto, 2020). 
Kemudian penelitian ini juga sejalan dengan penelitian terdahulu Paramita dkk yang menyatakan bahwa Siswa dan Guru di SMA Negeri 1 Sigi memiliki pengetahuan cara pengelohan sampah anorganik melalui prinsip Reduce, Reuse, dan Recycle (3R). dan Siswa di SMA Negeri l Sigi dapat membuat media pembelajaran IPA Fisika melalui pemanfaatan sampah anorganik dan mendorong Guru untuk menerapkan pembelajaran berbasis lingkungan. Hal ini ditandai dengan hasil angket respon siswa secara keseluruhan mengatakan bahwa 87,8\% sangat setuju terhadap program ini.(Paramita et al., 2020).

Sejalan dengan penelitian Novi Marliani yang menyatakan bahwa dalam pemanfaatan dan pengelolaan sampah harus melibatkan berbagai komponen masyarakat dan memperhatikan karakteristik sampah, karakteristik lingkungan serta keberadaan sosial-budaya masyarakat setempat. Sampah anorganiklah yang sangat berbahaya bagi kehidupan lingkungan. Berdasarkan hasil pembahasan di atas berikut bahwa proses perencanaan pemanfaatan dan pengelolaan sampah rumah tangga di lingkungan masyarakat dimulai dari tahap pembuatan kesepakatan awal, perumusan masalah, identifikasi daya dukung, dan yang paling utama adalah peran serta masyarakat dalam pemanfaatan dan pengelolaan sampah rumah tangga(Marliani, 2015).

Adapun beberapa penelitian relevan terkait pentingnya media pembelajaran dalam menunjang hasil belajar adalah sebagai berikut: Abdul Wahid menyatakan bahwa media pendidikan penting dalam meningkatkan prestasi belajar peserta didik. Media pendidikan dan pembelajaran dapat bermanfaat sebagai alat penyampai materi pelajaran yang dapat diseragamkan, proses pembelajaran menjadi lebih jelas dan menarik, proses pembelajaran menjadi lebih interaktif, efisiensi dalam waktu dan tenaga, meningkatkan kualitas hasil belajar peserta didik, $m$ edia memungkinkan proses pembelajaran dapat dilakukan di mana saja dan kapan saja, media dapat menumbuhkan sikap positip peserta didik terhadap materi serta proses belajar dan pembelajaran (Wahid, 2018). M. Miftah dalam penelitiannya menyatakan bahwa Media dalam dunia Pendidikan pada umumnya dan pembelajaran secara khusus telah memberikan kontribusi atau sumbangan besar dalam rangka menyediakan dan melaksanakan pemecahan masalah guna memberi kemungkinan belajar. Pemecahan masalah belajar yang ditawarkan ini berupa penyediaan sumber belajar, baik yang sengaja dirancang maupun yang dipilih dan kemudian dimanfaatkan (M. Miftah, 2013). Teni Nurrita dalam penelitiannya menyatakan bahwa media pembelajaran adalah alat yang membantu proses belajar mengajar sehingga pesan yang disampaikan menjadi lebih jelas dan tujuan pendidikan/pembelajaran dapat tercapai dengan efektif dan efisien. Hasil belajar adalah hasil yang diberikan kepada siswa berupa penilaian setelah mengikuti proses pembelajaran dengan menilai pengetahuan, sikap, ketrampilan diri siswa dengan adanya perubahan tingkah laku (Teni Nurrita, 2018). Supriyono juga menyatakan bahwa penggunaan media dalam proses pembelajaran di ruang kelas ternyata berimplikasi terhadap beberapa hal antara lain: (a) pada diri guru itu sendiri, yakni dengan penggunaan media dapat memudahkan guru dalam melaksanakan proses pembelajaran di ruang kelas; (b) terhadap diri siswa, dimana dengan penggunaan media dalam proses pembelajaran dapat merangsang siswa untuk belajar secara lebih aktif, inovatif, kreatif, dan menyenangkan; (c) 
terhadap proses pembelajaran di ruang kekas, yakni dapat membantu guru dalam penyampaian materi pelajaran, dan dapat menciptakan suasana belajar yang aktif, inovatif, kreatif, dan menyenangkan (PAIKEM) (Supriyono, 2018).

\section{Metodelogi}

Penelitian ini dilakukan di Madrasah Tsanawiyah Safinatussalamah AlMunawarah. Dayah Safinatussalamah Al-Munawarah terletak di Desa Blang Panyang Kecamatan Muara Satu Kota Lhokseumawe. Waktu penelitian dilakukan pada tanggal 9 Agustus 2021 dan adapun tempat penelitian yaitu di Madrasah Tsanawiyah Safinatussalamah Al-Munawarah. Populasi dan sampel, Adapun yang menjadi populasi dalam penelitian ini adalah seluruh siswa MTsN di Pesantren Safinatussalamah Al-Munawarah dan yang menjadi sampel adalah siswa kelas 1 MTsN Safinatussalamah Al-Munawarah.

Dalam penelitian ini penulis menggunakan pendekatan 'kualitatif' penelitian yang dilakukan bersifat deskriktif yaitu untuk mengetahui atau menggambarkan kenyataan dari kejadian yang diteliti sehingga memudahkan penulis untuk mendapatkan data yang objektif dalam rangka mengetahui dan memahami suatu kondisi dan fenomena yang ada.

Instrument dalam penelitian ini adalah lembar observasi dan dokumentasi yang di sajikan sebagai berikut: 1 . Pengamatan (Observasi), Dalam hal ini, peneliti menggunakan observasi partipasi pasif yang merupakan observasi yang dilakukan peneliti dengan cara mendatangani langsung, melihat, kemudian mencatat perilaku sebagimana yang terjadi pada keadaan yang sebenarnya. Mengamati sendiri ketempat kegiatan orang yang diamati, tetapi tidak ikut terlibat dalam kegiatan tersebut". Maka dalam penelitian ini peneliti mengamati langsung proses pemanfaatan sampah anorganik menjadi media pembelajaran. 2. Dokumentasi merupakan teknik pengumpulan data secara tidak langsung kepada subjek penelitian. Dalam menjalankan teknik ini, peneliti memperoleh data langsung dari subjek yang diteliti kemudian menarik kesimpulan dari sumber dokumentasi objek penelitian.

Teknik analisis data yang digunakan dalam penelitian ini: (1) Pengumpulan Data, Pengumpulan data adalah usaha yang dilakukan untuk mencari dan mengumpulkan data datayang dianggap relevan dengan kebutuhan data dalam judul yang diangkat dalam suatu penelitian. (2) Reduksi Data, Reduksi data adalah langkah yang dilakukan setelah pengumpulan data dan memasukannya ke dalam suatu penelitian dengan ketentuan data yang sudah terkumpul harus relevan. (3) Verifikasi Data, Verifikasi data adalah suatu upaya untuk menemukan kesesuain dan kelayakan data penelitian sehingga data tersebut dianggap mampu memberikan hasil yang relevan dan sesuai. (4) Menarik Kesimpulan, Kesimpulan diambil dari pemahaman penulis terhadap informasi-informasi yang diperoleh dari hasil verifikasi data. Kesimpulan yang diambil diharapkan mampu memberikan gambaran yang jelas dan terarah sesuai dengan maksud dari penelitian.

\section{Hasil Penelitian}

Penelitian pemanfaatan sampah anorganik sebagai media pembelajaran yang di lakukan di Madrasah Tsanawiyah Safinatussalamah Al-Munawarah, di 
peroleh hasil berdasarkan tahapan pelaksanaannya, sehingga mempermudah siswa dalam mengenali media pembelajaran dari sampah anorganik. Adapun tahapan pelaksanaan penelitian yang di lakukan siswa adalah sebagai berikut:

Tabel. 1. Tahapan Pelaksanaan Pemanfaatan Sampah Anorganik Sebagai Media Pembelajaran.

\begin{tabular}{|c|c|c|c|c|}
\hline No & Judul Kegiatan & $\begin{array}{l}\text { Alat } \\
\text { Bahan }\end{array}$ & Kegiatan Siswa & $\begin{array}{ll}\text { Kegiatan } & \text { Tim } \\
\text { Pengabdian } & \end{array}$ \\
\hline 1 & $\begin{array}{l}\text { Pembuatan } \\
\text { Bingkai Dari } \\
\text { Limbah } \\
\text { Anorganik } \\
\text { bergambar alat } \\
\text { peraga IPA }\end{array}$ & $\begin{array}{l}\text { - Kardus } \\
\text { Bekas } \\
\text { - Plastik } \\
\text { Bungkusan } \\
\text { Permen } \\
\text { - Lem perekat } \\
\text { - Kacang } \\
\text { Hijau } \\
\text { - Gambar alat } \\
\text { peraga IPA }\end{array}$ & $\begin{array}{l}\text { - Membuat bingkai } \\
\text { dari bahan limbah } \\
\text { anorganik dengan } \\
\text { cara: } \\
\text { - Memotong kardus } \\
\text { menjadi segi } 4 \\
\text { - Memotong kecil } \\
\text { bungkusan } \\
\text { permen, } \\
\text { kemudian } \\
\text { menempelkan di } \\
\text { sekeliling kardus } \\
\text { membentuk } \\
\text { bingkai foto } \\
\text { - Menempelkan } \\
\text { gambar alat } \\
\text { peraga ipa di } \\
\text { tengah bingkai } \\
\text { foto } \\
\text { - Kemudian } \\
\text { menempelkan } \\
\text { kacang hijau di } \\
\text { atas gambar alat } \\
\text { peraga IPA }\end{array}$ & $\begin{array}{l}\text { - Menyampaikan } \\
\text { konsep } \\
\text { Pembelajaran } \\
\text { yang berkaitan } \\
\text { dengan } \\
\text { pelatihan } \\
\text { - Membimbing } \\
\text { siswa pada saat } \\
\text { kegiatan } \\
\text { berlangsung } \\
\text { - Melakukan } \\
\text { penilaian yang } \\
\text { meliputi: } \\
\text { - Penilaian } \\
\text { produk } \\
\text { Kerapian } \\
\text { - Presentasi } \\
\text { konsep IPA } \\
\text { yang } \\
\text { terkandung } \\
\text { dalam } \\
\text { gambar }\end{array}$ \\
\hline
\end{tabular}

Pembuatan media pembelajaran dengan memanfaatkan sampah anorganik ini berjalan dengan baik dengan adaanya dukungan dan kerjasama antara pihak Madrasah, guru dan siswa. Media pembelajaran yang kreatif dan inovatif adalah media pembelajaran yang mampu menyampaikan materi dengan baik kepada siswa sehingga mewujudkan pembelajaran yang bermakna dengan memanfaatkan barang-barang disekitar. Salah satunya adalah pemanfaatan sampah anorganik yang ada di sekolah untuk dijadikan sebagai media pembelajaran sekaligus melatih siswa untuk berkreasi dan berinovasi menggunakan bahan alam. Pembelajaran yang bermakna juga dapat terwujud dengan melibatkan siswa dalam proses pembelajaran.

Adapun hasil perolehan dari kegiatan siswa adalah dapat disimpulkan bahwa penggunaan media gambar dapat meningkatkan hasil belajar siswa pada pembelajaran IPA, hal ini di tunjukan dari motivasi dan kreatifitas yang muncul pada saat kegiatan pembuatan media pembelajaran berlangsung. 


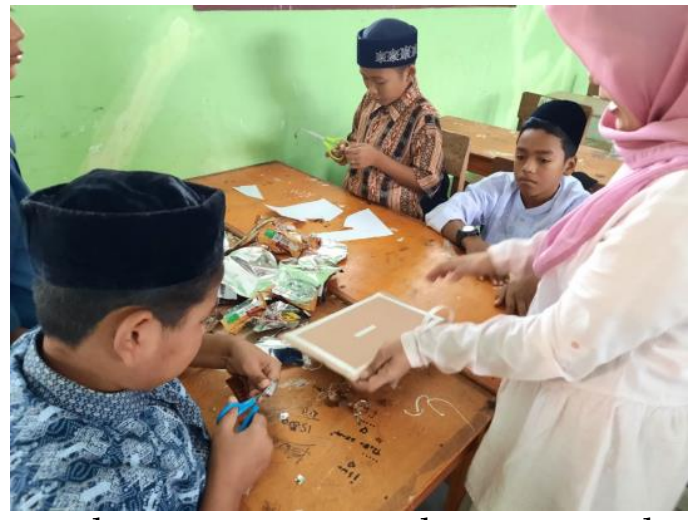

Gambar l. Kegiatan pembuatan proyek Kelompok Bandul

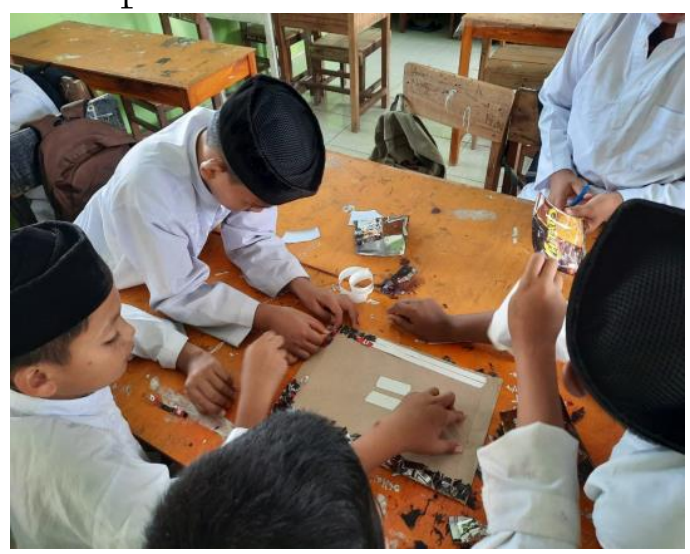

Gambar 3. Kegiatan pembuatan proyek Kelompok Lup

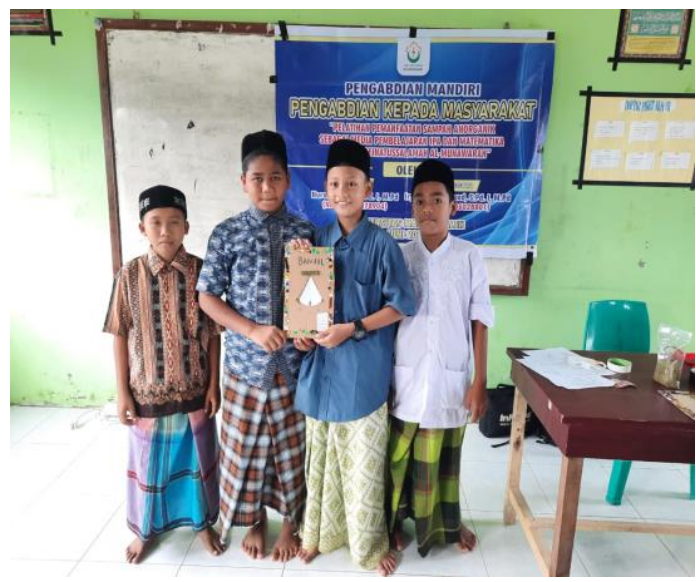

Gambar 5. Kegiatan Presentasi Hasil

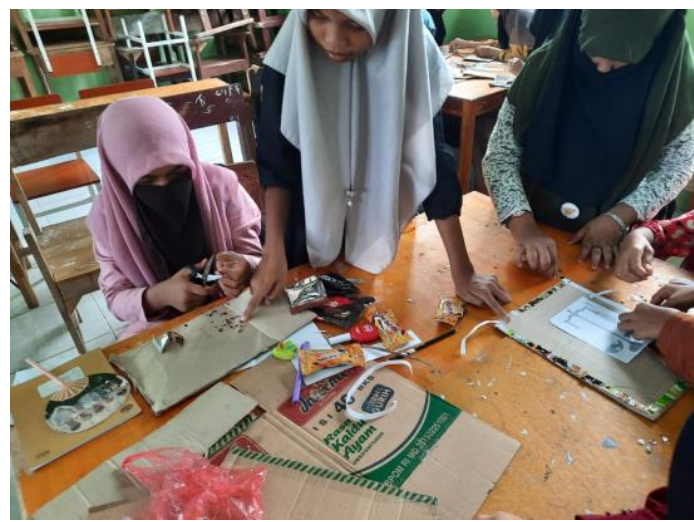

Gambar 2. Kegiatan pembuatan proyek Kelompok Timbangan

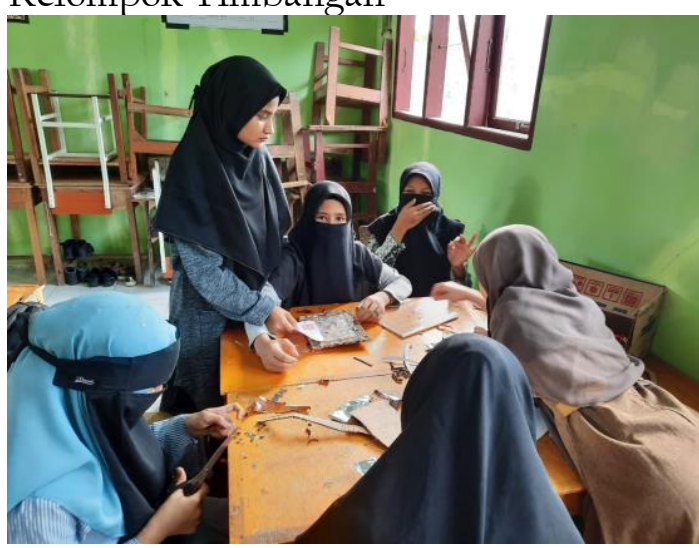

Gambar 4. Kegiatan pembuatan proyek Kelompok Katrol

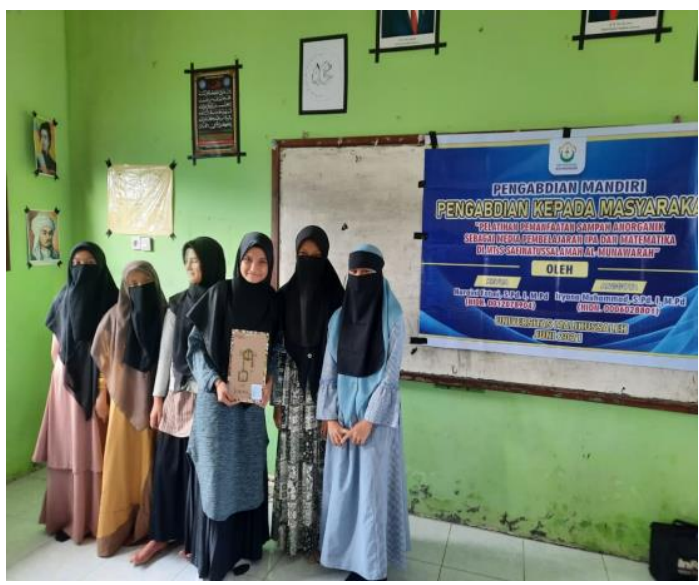

Gambar 6. Kegiatan Presentasi Hasil

\section{E. Pembahasan}

Sampah Anorganik merupakan sampah kering yang tidak mudah membusuk seperti: plastik, wadah pembungkus makanan, kertas, botol, kaleng dll. Pada kegiatan pengabdian ini, tim pengabdian melatih siswa memanfaatkan sampah anorganik untuk membuat media pembelajaran IPA, Adapun media yang 
dipilih dalam penelitian ini adalah bingkai foto. Hal yang menarik dari bingkai foto sebagai media pembelajaran IPA adalah bahan-bahan yang digunakan dalam pembuatan media ini semuanya mudah didapatkan dan semuanya berkaitan dengan IPA khususnya lingkungan. Sehingga membuat siswa lebih mengenal tentang bandul, katrol, timbangan dua lengan dan lup. Gambar alat peraga ini merupakan bagian dari pembelajaran IPA di tingkat Tsanawiyah. Maka pengertian masing-masing dari alat peraga IPA yang digunakan siswa dalam pelatihan adalah: lup merupakan alat optik yang terdiri atas sebuah lensa cembung. Lup digunakan untuk melihat benda-benda kecil agar nampak lebih besar dan jelas. Bandul merupakan Gerakan bolak balik yang dapat dihitung secara periodik. Katrol merupakan roda yang berputar pada porosnya kegunaannya untuk membantu mengangkat benda dengan gaya yang kecil. Timbangan dalam fisika disebut neraca yang berguna untuk mengukur masa atau berat benda. Adapun hasil karya proyek siswa dapat dilihat sebagai berikut:

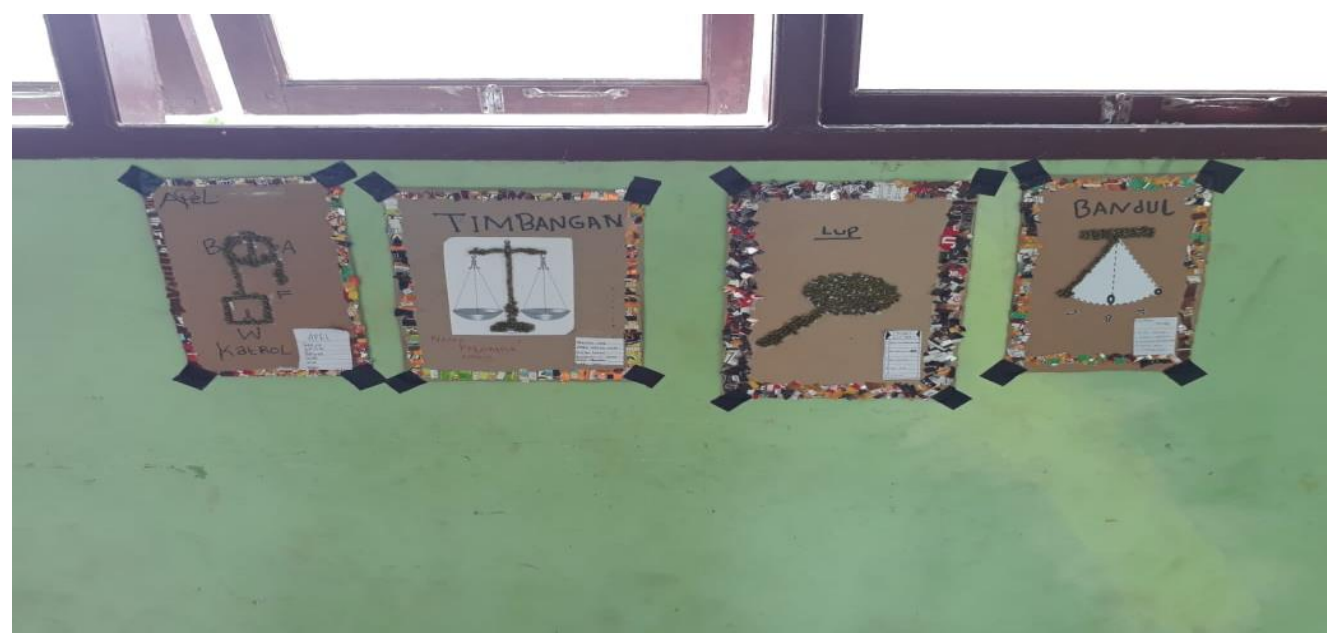

Gambar 7. Hasil Karya Proyek Pemanfaatan Sampah Anorganik sebagai Media Pembelajaran.

\section{F. Kesimpulan}

Penelitian ini dapat disimpulkan bahwa kegiatan ini mengajarkan siswa mencintai lingkungan dengan memanfaatkan sampah anorganik serta menjadikan limbah anorganik sebagai produk media pembelajaran dapat meningkatkan kreatifitas siswa dan hasil belajar, hal ini di karenakan siswa lebih memahami konsep pembelajaran dengan cara melihat dan mengerjakan melalui media pembelajaran.

\section{BIBLIOGRAFI}

Duda, H. J., Awang, I. S., \& Andri, A. (2018). PKM Pelatihan Pemanfaatan Bahan Bekas Sebagai Media Pembelajaran IPA bagi Kelompok Guru IPA. Jurnal Pengabdian Kepada Masyarakat, 8(1), 15. https://doi.org/10.30999/jpkm.v8il.195

M. Miftah. (2013). Peran Dan Fungsi Media Pembelajaran Sebagai Upaya Peningkatan Kemampuan Belajar Siswa. Jurnal KWANGSAN, 1(9), 1689-1699.

Manurung, R. (2008). Persepsi dan Partisipasi Siswa Sekolah Dasar dalam 
Pengelolaan Sampah di Lingkungan Sekolah. Junral Pendidikan Penabur, 7(10), 22-34.

Marliani, N. (2015). Pemanfaatan Limbah Rumah Tangga (Sampah Anorganik) Sebagai Bentuk Implementasi dari Pendidikan Lingkungan Hidup. Formatif: Jurnal Ilmiah Pendidikan MIPA, 4(2), 124-132. https://doi.org/10.30998/formatif.v4i2.146

Ni Komang Ayu Artiningsih, Sudharto Prawata Hadi, S. (2008). Peran Serta Masyarakat Dalam Pengelolaan Sampah Rumah Tangga. Jurnal Ilmiah UNTAG Semarang, Vol l(II), 107-114.

Nugraha, A., Sutjahjo, S. H., \& Amin, A. A. (2018). Analisis Persepsi Dan Partisipasi Masyarakat Terhadap Pengelolaan Sampah Rumah Tangga Di Jakarta Selatan. Jurnal Pengelolaan Sumberdaya Alam Dan Lingkungan (Journal of Natural Resources and Environmental Management), 8(1), 7-14. https://doi.org/10.29244/jpsl.8.1.7-14

Nurlaili, S. (2018). Pengenalan Eco-literacy Melalui Media Pembelajaran Dari Sampah di Sekolah Dasar. Journal AL-MUDARRIS, 1(2), 76. https://doi.org/10.32478/al-mudarris.vli2.171

Paramita, I., Alit, K., Untara, A., \& Wiwik, M. (2020). Pemanfaatan Sampah Anorganik sebagai Media Pembelajaran IPA Fisika pada Siswa SMA Negeri 1 Sigi. Jurnal Pendidikan Fisika Tadulako Online, 8(3), 12-16.

Pitri Ramadan, C., \& Vebrianto, R. (2020). Bingkai dari Limbah Anorganik sebagai Media Pembelajaran IPA Dalam Mengembangkan Kreativitas Siswa. Journal for Teachers and Learning, 1(1), 1-5.

Riswan, Sunoko, H. R., \& Hadiyanto, A. (2015). Kesadaran Lingkungan. Jurnal Ilmu Lingkungan, 9(1), 31-39. https://ejournal.undip.ac.id/index.php/ilmulingkungan/article/view/2085

Supriyono. (2018). Pentingnya Media Pembelajaran Untuk Meningkatkan Minat Belajar Siswa SD. Edustream: Jurnal Pendidikan Dasar, II(1), 43-48. https://journal.unesa.ac.id/index.php/jpd/article/view/6262/3180

Taufiq, A., \& Maulana, F. M. (2015). Sosialisasi Sampah Organik dan Non Organik serta Pelatihan Kreasi Sampah. Jurnal Inovasi Dan Kewirausahaan, 4(1), $68-73$.

Teni Nurrita. (2018). Kata Kunci :Pengembangan media pembelajaran untuk meningkatkan hasil belajar siswa. Jurnal Misykat, 03(01), 171.

Wahid, A. (2018). Pentingnya Media Pembelajaran dalam Meningkatkan Prestasi Belajar. Istiqra, 5(2), 1-11.

Widiyaningrum, P., \& Purwantoyo, E. (2015). Evaluasi Partisipasi Siswa Dalam Pengelolaan Sampah Untuk Mendukung Program Sekolah Adiwiyata. Indonesian Journal of Conservation, 4(1). 